For more than 100 years, the U.S. Geological Survey (USGS) has provided the information needed to manage the Nation's earth resources, to mitigate natural hazards, and to understand the environment. In Washington, the USGS works cooperatively with local, State, and other Federal agencies, as well as with universities, to study earth science issues.

\section{Earthquakes in the Pacific Northwest}

Long time intervals between large-magnitude earthquakes in the Pacific Northwest make predicting them particularly difficult. So that better predictions can be made, the USGS, in cooperation with university researchers and the Geological Survey of Canada, is using acoustic techniques to look at rock layers beneath long, broad strips across the Pacific Northwest. For example, in September 1995, the USGS and cooperating scientists recorded acoustic images of rocks beneath a 320-kilometer east/west transect in southwestern Washington. The scientists use these transects to identify subsurface geologic structures that are associated with earthquake activity. The presence or absence of such structures beneath now-seismically quiet areas indicates the likelihood of future earthquakes.

To help planners reduce the risk from large-magnitude earthquakes, the USGS made computer simulations of the stresses that build up in rocks under the Pacific Northwest. The simulations indicate that potential earthquakes in Washington result from a complex balance of forces applied along a major fault offshore of British Columbia and another fault offshore of Washington and Oregon. More earthquake facts are on the World Wide Web and may be accessed at:

http://quake.wr.usgs.gov

\section{Tsunamis-Hazards From Earthquakes In Puget Sound}

Earthquakes can generate tsunamis, which are great waves produced by the sudden movement of the earth beneath the sea. To assess the hazards of tsunamis, USGS researchers ran computer simulations of a tsunami generated by a disturbance of the Seattle Fault, which is a historically active fault that cuts across Puget Sound. In the simulations, the initial disturbance produced a large tsunami that was about 23 feet high (fig. 1A). Four minutes later, the waves had traveled far; a wave that was nearly 12 feet high lashed the Seattle waterfront to the north while another headed south to the tip of Vashon Island (fig. 1B). About 20 minutes later, after the tsunami had traveled 20 miles south to Tacoma, it was about 6.6 feet high.

Coupled with estimates of earthquake recurrence intervals and the extent and recent activity of faults, these simulations can define the hazards of tsunamis caused by landslides and shifting faults.

\section{Underwater Landslides}

Triggered by prehistoric earthquakes, landslides that lie on the floor of Lake Washington and Puget Sound may indicate the threat of future landslides in the SeattleTacoma area. By using acoustic techniques, the USGS, in cooperation with the Washington State Department of Natural Resources (WDNR), mapped the distribution, size, and
Index of Subjects

Earthquakes in the Pacific Northwest Tsunamis-Hazards From Earthquakes In Puget Sound

Underwater Landslides

Volcanic Hazards

Long-Term Water Supply Linked to Climate Change

How Do Streams and Ground Water Affect Each Other?

National Water-Quality Assessment

Topographic Mapping

Geology of Mount St. Helens

Earth Science Information

Water-Data Collection

Water Data on the World Wide Web

Washington Fisheries

shape of landslide deposits in Lake Washington and Elliott and Commencement Bays in Puget Sound. This study revealed previously unrecognized landslide deposits in the southern part of the Sound. Analyses are used to assess the potential for damage to piers, bridges, and other structures in and near water. In conjunction with this study, the USGS, in cooperation with the U.S. Environmental Protection Agency (USEPA) and the National Oceanic and Atmospheric Administration, recorded acoustic images at three Superfund sites along the shore of Puget Sound to understand better the nature and
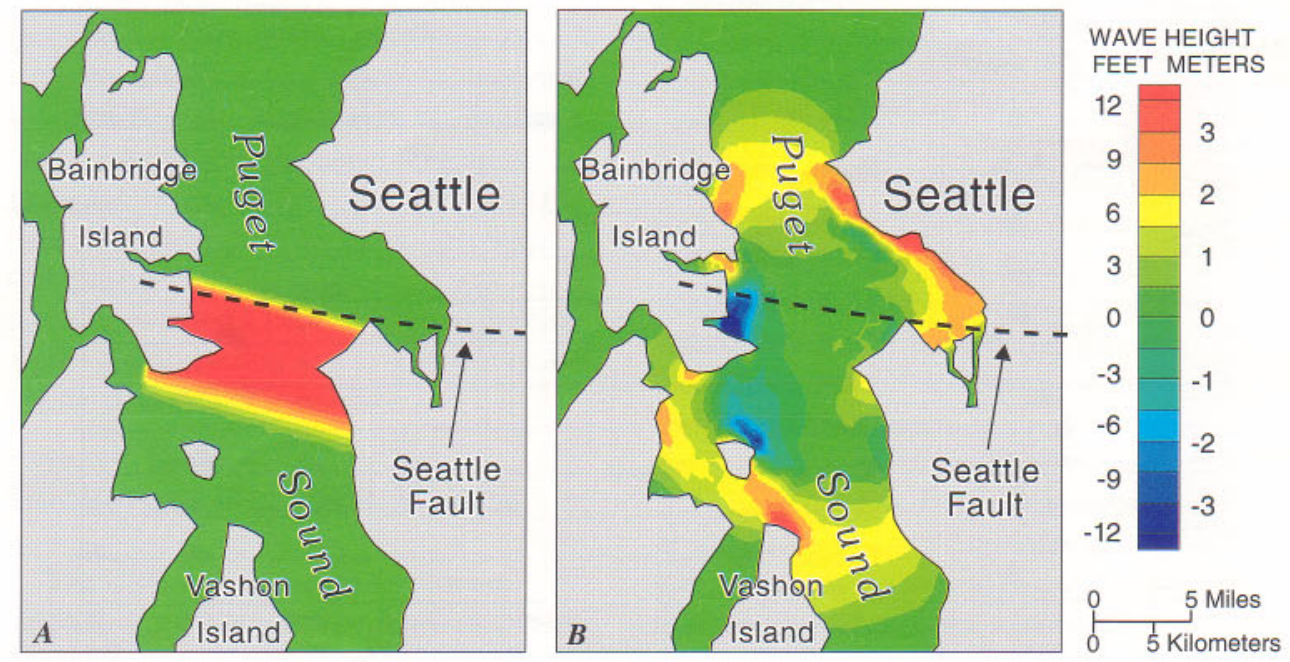

Figure 1. Simulated tsunami. $A$, At the start of the earthquake; $B$, Four minutes later. 
extent of contaminant migration from these sites to the offshore. The USEPA and the WDNR are using the USGS data to remediate seafloor contaminated by hazardous waste.

http://walrus.wr.usgs.gov

\section{Volcanic Hazards}

Seven volcanoes in the Cascade Range have erupted during the past few hundred years (fig. 2), two of them during this century. Future eruptions pose serious hazards to communities, aviation, and interstate commerce in Washington, Oregon, and northern California. In recent studies, the USGS has demonstrated that losses of lives and property from future eruptions can be reduced substantially through effective land-use planning and timely warnings of impending volcanic activity. Therefore, the USGS, in cooperation with various Federal, State, and county agencies, is studying the far-reaching effects of past eruptions, monitoring for signs of renewed volcanic unrest, developing new monitoring and predictive tools, and exchanging information with concerned officials, agencies, and citizens to identify and mitigate hazards from future eruptions in the Northwestern United States.

In 1995, the USGS released updated volcano-hazard assessments for each of the five Cascade volcanoes in Washington. A detailed geologic map of Mount Adams also was released in 1995, and similar mapping projects are now underway at Mount Baker, Mount Rainier, and Mount St. Helens. Mount Rainier is one of two U.S. volcanoes designated for special study during the
United Nations' International Decade for Natural Disaster Reduction. As part of this effort, the USGS recently released a quantitative assessment of debris-flow hazards at Mount Rainier. Other work in progress includes a video on volcano hazards at Mount Rainier, exhibits, teacher workshops, and Fact Sheets on the geology and hazard potential at Mount Rainier.

http://vulcan.wr.usgs.gov

\section{Long-Term Water Supply Linked to Climate Change}

Since 1977, annual streamflow in western Washington has decreased on average about 14,000 cubic feet per second-nearly the equivalent of shutting off the Skagit River. Annual precipitation also has decreased during the same period. The USGS has linked these decreases, which are affecting the long-term water supply of the area, to shifts in the climate of the Pacific Northwest.

Because the historical record of Pacific Northwest precipitation and streamflow data, as well as Northern Hemisphere atmospheric and temperature data, has indicated three distinguishable climate periods, the USGS divided the annual records into three periods for analysis - the pre-1947 record, the base record from 1947 to 1976, and the post-1976 record. The analysis involved examining the means and ratios of means of precipitation totals from 50 sites in western Washington and streamflow averages from 112 sites in Washington, Oregon, and Idaho.

The analysis revealed that mean precipitation and streamflow during the pre-1947
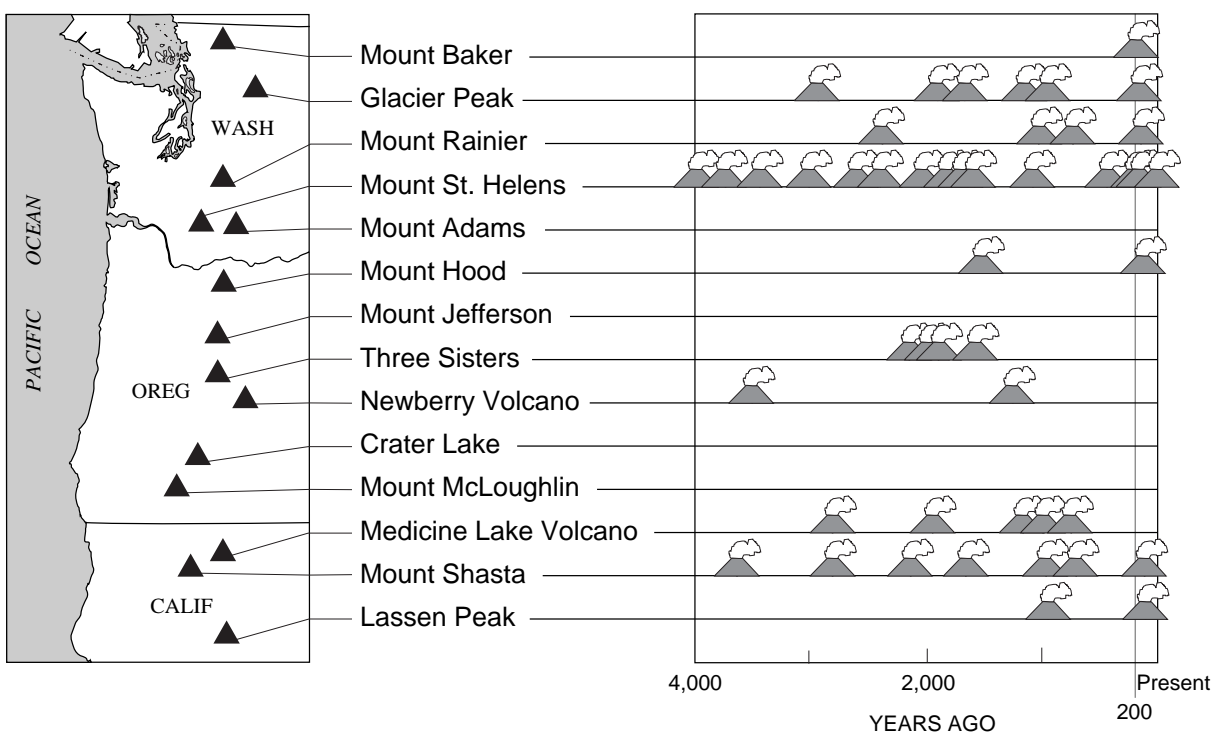

Figure 2. Cascade Range eruptions during the past 4,000 years.

and the post-1976 periods were less than during the base period, although average rainfall in March and April was actually greater in the post-1976 period than in the wetter base period.

In the short run, the USGS analysis suggests that the water supply, though under greater demand, is not being renewed as fast as it was two to four decades ago because of the Pacific Northwest's currently drier and warmer climate. In the long term, the analysis indicates that managing the Pacific Northwest's water resources will require better understanding of the role of climate.

\section{How Do Streams and Ground Water Affect Each Other?}

Because water is in limited supply in many basins, withdrawals from streams are allocated by permit from the Washington State Department of Ecology. With streamflow fully allocated in some basins, groundwater development has increased.

There are connections between a basin's ground water and its streams. Called hydraulic continuity, this interaction between ground and surface waters has only recently figured in the water-rights permitting process. As a result, permitted withdrawals in some basins may exceed the total volume of water available for development.

To assist the State in resolving the situation to the benefit of all water users, the USGS began an education program to explain what happens between ground water and surface water. The USGS, in cooperation with the Washington State Department of Ecology, developed an effective training tool-a computer modeling program that simulates the effects of well pumping on streamflow in a basin typical of the Puget Sound Lowland.

"The USGS model demonstrates graphically how ground water and surface water affect each other," said Linton L. Wildrick, hydrogeologist with the Washington State Department of Ecology, "which helps us explain these concepts to the public and the Legislature."

The USGS also is using the model in presentations to local water-resource managers.

\section{National Water-Quality Assessment}

The USGS's National Water-Quality Assessment (NAWQA) Program collects 
and disseminates information about the quality of water resources in 60 selected basins of the Nation, including 3 in Washington. Its purpose is to assess current conditions and trends in water quality and to gain a better understanding of the major factors that affect water quality. An important goal of the NAWQA Program is to make relevant findings about water quality available to the public, as well as to decisionmakers.

A NAWQA Program study carried out in the Yakima River Basin from 1986 to 1991 found high concentrations of the banned insecticide DDT in soil, streams, and some fish. There is some evidence that improved agricultural practices, such as drip and sprinkler irrigation, have reduced soil erosion, which is the main source of DDT in streams.

A current NAWQA Program study focuses on the Central Columbia Plateau, which is another area where water quality is heavily influenced by agricultural practices. Nitrate concentrations exceed USEPA drinking water standards in 20 percent of drinking water wells in the study area. High nitrate concentrations in ground water are directly related to using large quantities of nitrogen fertilizers and irrigation and may indicate that pesticides used along with fertilizers also are in the ground water.

In 1994, the NAWQA Program began a study of the high-precipitation, densely populated area of the Puget Sound Lowland, which contains water resources of major economic and ecological importance. This study is looking at urban and agricultural areas and focuses on water-quality issues such as occurrence and concentration of volatile organic compounds, pesticides in streams and ground water, and the health of in-stream habitats.

To ensure that results will be relevant, representatives of local, State, and Federal agencies, universities, and private groups meet with USGS scientists about twice a year to review study results and their implications and to advise on plans for the future. One member, Phillip Crawford of Washington State University Cooperative Extension, has commented that the focus on water quality provided by the NAWQA Program produces a "teachable moment" that allows people with historically diverse interests, including farmers, developers, and environmental and conservation groups, to build consensus.

http://wwwdwatcm.wr.usgs.gov/ccpt.nawqa.html

\section{Topographic Mapping}

Among the most popular and versatile products of the USGS are its 1:24,000-scale topographic maps (1 inch on the map represents 2,000 feet on the ground). These maps depict natural and cultural features of the landscape, such as lakes and streams, highways and railroads, boundaries, and geographic names. Washington is covered by 1,456 maps at this scale. These maps have long been favorites with the general public for outdoor uses, as well as with scientists and engineers for technical applications.

Today, scientists and engineers depend on computerized base maps to provide geographic context for their research and analyses. The USGS is working to ensure the availability of accurate cartographic data to help address the Nation's pressing resource and public safety issues, such as groundwater supply and quality, natural hazards, and land and resource management.

The USGS is addressing the growing public- and private-sector demand for digital data that describe transportation networks, hydrography, boundaries, Public Land Surveys, and land elevation. To streamline production of these data and reduce costs, the USGS, in cooperation with the WDNR and other Federal, State, and local government agencies, is working on a program called Data '96. This program, which uses private-sector contracting, acquires new data and combines them with data contributed by cooperating agencies to complete digital data coverage for the State of Washington by 1996. The data are used to manage Federal and State lands better and to provide local and tribal governments with low-cost data.

A major benefit of the program is that it gives private industry and the public access to the same digital data used by government agencies. Initially, the data are being distributed by the WDNR to cooperating agencies. In the future, the USGS expects to make the data available to Internet users. The State Geographic Information Council was recently awarded a Federal grant to develop a pilot digital catalog as a first step in making the data available on-line.

\section{Geology of Mount St. Helens}

The USGS, in cooperation with the WDNR, is working on a geologic map of Mount St. Helens National Volcanic Monument. The map represents an important tool for understanding the geologic setting of Mount St. Helens and provides an essential framework for related detailed geologic mapping and analysis of the volcano and its hazards by scientists of the USGS Cascades Volcano Observatory.

http://vulcan.wr.usgs.gov

\section{Earth Science Information}

The USGS operates an Earth Science Information Center (ESIC) in Spokane. This office specializes in providing earth science information on the Pacific Northwest region to the public. The ESIC inventory includes USGS open-file reports and topographic maps, land-use and land-cover data, and maps and reports prepared by the Bureau of Land Management, the Defense Mapping Agency, and the U.S. Fish and Wildlife Service's National Wetlands Inventory, for Washington, Oregon, Idaho, and Montana. The office also conducts data-base searches and places orders for digital cartographic data, aerial photography, and historical maps.

Other State ESIC affiliates for USGS products are the Washington State Library, Information Services Division, in Olympia and the University of Washington, Library Map Collection and Cartographic Information Services, in Seattle.

\section{Water-Data Collection}

The USGS, in cooperation with local, State, and other Federal agencies, collects and disseminates such water data as streamflow, reservoir and lake stage, ground-water level, water chemistry and water-quality, and climate. Much of the data collected by the USGS in Washington and the Nation is stored in the National Water Information System and are published annually.

The record-breaking Pacific Northwest floods of November 1995 illustrate the relevance of current data collection and dissemination programs. The floods, which were set off by rapid snowmelt during a series of rainstorms, caused the Governor to declare a state of emergency in 14 Washington counties. Although road closures made many of the USGS's 250 stream-gaging stations in the State inaccessible, satellite telemetry and automated data-relay systems continued to supply river-height data from stranded stations within minutes to emergency management and information agencies. County emergency agencies, the U.S. Army Corps of Engineers, and the National Weather Ser- 
vice depended on the USGS data to develop flood forecasts, to manage reservoir levels, and to warn residents of flooding in lowlying areas.

The USGS data bases cover about the last 100 years in Washington. These historical data include flow for more than 1,100 discontinued streamflow-gaging sites, intermittent records of flow for more than 5,000 streamflow-gaging sites, and water-quality data for surface and ground waters at more than 10,000 sites. These historical data constitute a long-term record of the quantity and quality of the State's surface- and groundwater resources and help provide for the orderly, informed development and management of Washington's water resources.

\section{Water Data on the World Wide Web}

The USGS is working to make water data more accessible to those who want it and has begun to place data products on the World Wide Web. Through commercial computer services, millions of Americans can now monitor river height and flow for more than 70 streamflow-gaging sites in Washington. Historical streamflow records also are online and more information is being added as the information becomes available. The data products - and tracking the next big flood—can be accessed through the USGS Washington District Home Page at:

\section{http://wwwdwatcm.wr.usgs.gov}

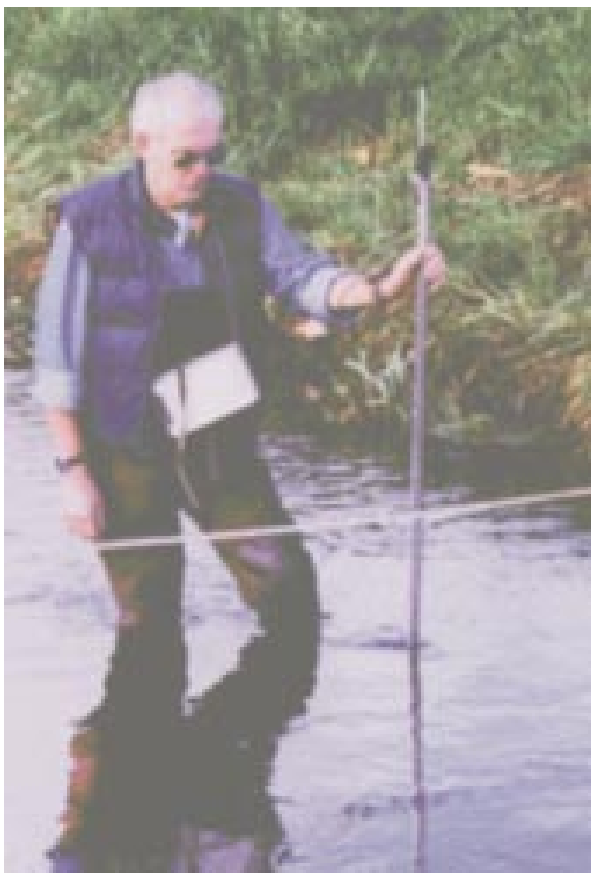

Figure 3. Measuring the flow in a Washington stream to calibrate a streamflow-gaging station.

\section{Washington Fisheries Studies}

The USGS Biological Resources Division (BRD, formerly the National Biological Service) conducts research on issues critical to the use and management of natural resources. The BRD's Northwest Biological Science Center (NBSC) in Seattle undertakes projects throughout the Pacific Northwest. Research includes studies on salmon populations, which are vitally important to local economies but which are in severe decline in the Pacific Northwest; detection and diagnosis of common and exotic fish diseases in the NBSC's unique disease containment laboratory; research to understand interdependencies among fish, wildlife, and their habitats; and pioneering the use of techniques, such as molecular biology, to gauge ecosystem health prior to severe problems.

The NBSC's Columbia River Research Laboratory in Cook addresses salmon and other fishery issues throughout the Columbia River Basin. Current research includes the study of basic habitat requirements, movements, and survival of salmon, trout, and white sturgeon in the Columbia and the Snake Rivers; the effects of dam operations on the migration passage and survival of fish; and susceptibility of young fish to predation, which results from conversion of the free-flowing river to a series of reservoirs that contain introduced predators.

The NBSC's Marrowstone Island Field Station in Nordland carries out research on marine species and the saltwater life stages of salmon and steelhead. Projects at the facility include characterizing the effects of stress and disease on salmon and trout as they transform from a freshwater to a saltwater metabolism, the effects of a spill of crude oil from a tanker ship on disease-free herring spawned and grown at Marrowstone, and work toward first-time spawning of Pacific Halibut in captivity, which may be a key to future conservation efforts for this species.

The Washington Cooperative Fish and Wildlife Research Unit is housed at the University of Washington, where Federal scientists teach, advise, and conduct graduatelevel programs. Research at the Unit focuses on the indirect impacts of contaminants on wildlife, detection of pollution-mediated effects on various taxa and communities (aquatic and terrestrial), the management of anadromous fish; and population modeling of wildlife.
USGS State representative

1201 Pacific Ave., Suite 600

Tacoma, WA 98402

(206) 593-6510

Fax: (206) 593-6514

Email:dc_wa@usgs.gov

Additional earth science information can be found by accessing the USGS Home Page on the World Wide Web at http://www.usgs.gov/

For more information on all USGS reports and products (including maps, images, and computerized data), call

1-800-USA-MAPS

The USGS provides maps, reports, and information to help others meet their needs to manage, develop, and protect America's water, energy, mineral, biological, and land resources. We help find the natural resources needed to build tomorrow and supply the scientific understanding needed to help minimize or mitigate the effects of natural hazards and environmental damage caused by natural and human activities. The results of our efforts touch the daily life of almost every American. 